\title{
Partial Shading Conditions of Solar Photovoltaic System
}

\author{
G.Esakkimuthu, Rajesh Krishnasamy, Ramkumar Aathi,
}

\begin{abstract}
Now a day's Renewable Energy like Solar Photo voltaic system play on important role on the Renewable Energy sector. Most of the Power losses dependent on the Partial shading conditions lot of Methods are available to predict the MPPT under partial shading conditions. In This paper gives the survey of the different MPPT strategy (or) Technique connected to solar photovoltaic (PV) system accessible until January, 2019. $A$ various number of researchers report on various sorts of MPPT methods for a SPVA system together with usage. For as every methods are having some of advantages and disadvantages. Hence, a proper review of these method is very significant [31]. Various factors affecting the solar photo voltaic system performance such as solar irradiance, Temperature, soiling dust etc. Mainly the partial shading conditions are affecting the constant load Application due to sudden change of irradiance by cloud movement and also moving object near the solar Photo voltaic panel. So most of the researchers are concentrating on the partial shading conditions of the solar Photo voltaic system.
\end{abstract}

Keywords : Maximum power point tracking technique (MPPT), Partial shading conditions (PSC), Solar Photo Voltaic Array (SPVA).

\section{INTRODUCTION}

Recent Years the usage of the electronic and electrical devices (or) equipment's are increased Due to the growing of population as well as many peoples are wanted sophisticated life it means that increasing the electrical energy consumption devices like Air conditioner, Air cooler , fan etc.. it will lead to demand on electricity, then stock and increase the use of ordinary sources, (for example, coal and oil, Diesel Generator etc.), Sun based photovoltaic (PV) vitality turns into a promising elective source as it is ubiquitous, openly accessible, condition benevolent, and also it has the low maintenance and operational costs. Therefore, the need of Photo Voltaic power systems is by all accounts expanded day by day for both off grid and grid-Tied means on grid method of Photo Voltaic power

Revised Manuscript Received on December 05, 2019.

G.Esakkimuthu, Electrical and Electronics Engineering, Kalasalingam Academy of Research and Education, Anand Nagar, Krishnannkoil, Virudhunagar, India, esakimuthu@klu.ac.in

Dr.Ramkumar Aathi, Electrical and Electronics Engineering, Kalasalingam Academy of Research and Education, Anand Nagar, Krishnannkoil, Virudhunagar, India a.ramkumar@klu.ac.in

Dr.Rajesh Krishnasamy, Electrical and Electronics Engineering, Kalasalingam Academy of Research and Education, Anand Nagar, Krishnankoil, Virudhunagar, India, rajeshkrishme1987@gmail.com generation. Therefore, an effective maximum power point tracking techniques are necessary to obtain the maximum output power at different natural conditions and afterward power the framework operating condition at that Maximum power point.

It is one of the type of controller part of the PV frameworks. Numerous sorts of MPPT procedures are as one with their execution are accounted for in the literature [31]. Customers are always feeling which type of MPPT controllers for a particular specified application. Tragically, just a couple of papers are accessible in this field incorporates dialogs on MPPT strategies until 2019. Therefor it is important to set up a survey that incorporates all the proficient and successful MPPT methods proposed before 2012 and after that until 2019. In this audit, an endeavor has additionally been made to think about the MPPT procedures based on their preferences, weaknesses and different parameters.

\section{PV ARRAY UNDER PARTIALLY SHADED CONDITIONS}

A Photo Voltaic module is constructed by series connected large number of Photo Voltaic cells. After that the Photo V oltaic modules can be again connected it may be series or parallel by the requirement of customer need it means that maximum voltage range with respect to type of application like water pumping [18]. Fig. (i) Demonstrates the current versus voltage $(\mathrm{I}-\mathrm{V})$ characteristic for the Photo Voltaic modules. The arrangement associated left side segment of the photograph voltaic modules is non shaded. Then series-connected right side portion of the photo voltaic module is lightly shaded. In the event that the arrangement associated Photo Voltaic modules are working at level of Ia, then the non-shaded portion of the photo voltaic module will work in the region forward bias condition, while the shaded portion of the photo voltaic module will be work in the reverse bias region. Subsequently, the shaded portion of the photo voltaic module will absorb electrical energy rather than providing it, and then it will be dissipated in terms of heat energy for all time harm the module it will lead to failure of photo voltaic cells [29]. 


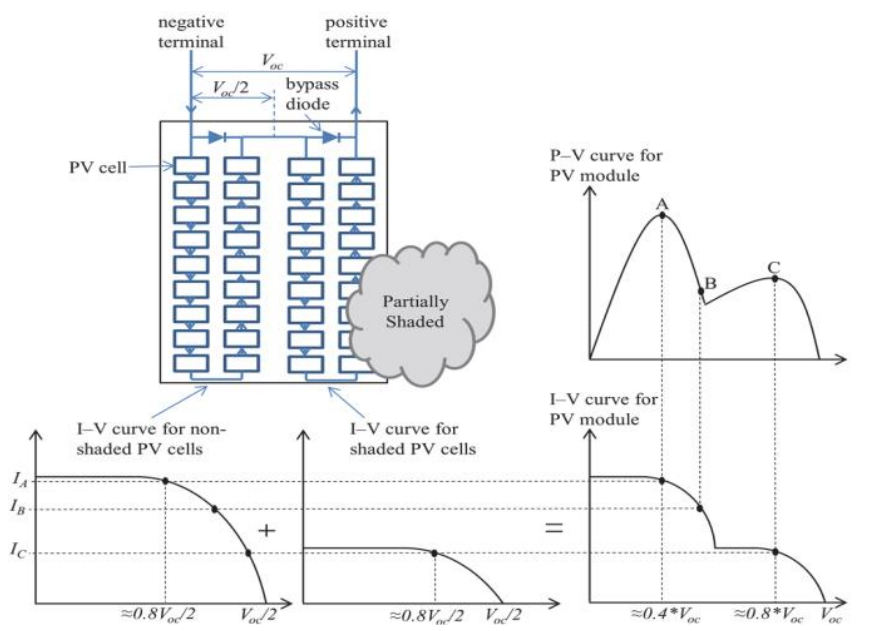

Author (s) can send paper in the given email address of the journal. There are two email address. It is compulsory to send paper in both email address.

\section{REVIEW ON MPPT TECHNIQUE}

The following mentioned various systems are broadly utilized Maximum Power Point Tracking strategies and connected on different Solar Photo voltaic applications such as space satellite, Water Pumping and various types of Application.

\section{A. Modified Incremental conductance Algorithm}

The Modified steady conductance calculation relies upon the slope of the Power-Voltage curve of the Photovoltaic model, it tends to be influenced by the sun based irradian level and ohmic changes of the load. In this computation uses the load change and voltage level of the Photo Voltaic module in the estimation. Subsequently, the impact of sun based illumination level and amphere changes because of burden and potential difference of the PV module should be thought on inside the algorithmic program. If there is no shade occur and likewise load obstruction stay consistent, no progressions made on the duty cycle. At the point when never shows signs of change happen in the sun based light level due to partial shading or any other factor like load, the estimation sets the standard inspiration to zero and after that picks the adjustments in the voltage and current degree of the Photo Voltaic module. If the computation perceive that both the changes are current and voltage characteristic on the Photo Voltaic Module, at that point the duty cycle is likewise expanded. Subsequently, so the incremental conductance algorithm is adjusted to beat the incorrect reaction during the expansion in sunlight based light level [30]. Utilizing these two qualities, the calculation decides the location of the operating point of the Photo Voltaic module in the characteristic of Poweer-Volatge curve.

\section{B. Modified velocity based PSO algorithm}

The C-Particle Swarm Optimization algorithm has a few parameters whose qualities should be selected by the researcher within a particular limit. The Particle Swarm Optimization additionally to boot use of random numbers within the rate equation that will makes the unpredictable result for Particle swarm optimization Technique. This gives plentiful degree to bring alterations into the predominant
PSO algorithmic to shape it further settled in nature with higher and sure outcomes. Introducing appropriate modifications may additionally create the Particle Swarm Optimization algorithmic rule far more economical in trailing the GMPP under PSC [6].This paper approach such type of modification to the Particle Swarm Optimization technique equation that increase the quality of the PSO technique, particularly for the case of GMPP under Partial Shading Conditions.

\section{Current compensation Method}

Solar Photo Voltaic Array constructed by multiple number of photo voltaic modules are associated in the way of series or parallel to get the maximum power from photo voltaic system and then fed into the power grid through an circuit breaker some electrical component like Transformer etc. , $S W$ out, and capacitor Cout . A each PV module having the parallel connection of fly back converter. The configuration of the device is moderately changed by dynamic the auxiliary diode by an influence of MOSFET switch, SW $(\mathrm{i}, \mathrm{j}) 2$ at the side of associate parallel diode this modifications are accustomed implement the planned theme. The transformers of the considerable number of converters are indistinguishable and have about equivalent charging inductance, $\operatorname{Lm}(i, j)$. The capacitor output $\mathrm{C}$ is like a direct current supply for every of those rectifiers. Everywhere assortment of $m$ number of strand within the array with every strand having $n$ number of arrangement associated modules, it can be noted, by $i$ and $j$ during a generalized manner, whenever $i=1: m$ and $j=1: n$. Every fly-back rectifier works in two processes, traditional fly-back process and the resonant MPPT proess [7].

\section{Enhanced Leader Particle Swarm Optimization}

Enhanced Leader-Particle Swarm Optimization technique is associate degree joining of practical transformations on the quality PSO method to make extra arbitrariness in control factors. This type of technique was first projected by d, A. Rezaee in so very much misused as of late. Adoption this methodology is appropriate to the Maximum Power Point Tracking disadvantage with as in the extra changes not alone produce irregularity to free from nearby minima however accelerates the convergence process. Both the on top of aforementioned things are urgent for a bio traced technique once connected to MPPT applications. The iterative methodologies are pursued for update the atom position in look space by the random initialization. The higher fitness of particle is noted from the evaluated best particle (Pbest) of goodness .After that before mutation the velocity of the particle and also control variable position should be updated for the quality of Particle Swam Optimization technique. This kind of behavior is same as for the ELPSO and also conventional Particle Swarm Optimization technique. Therefore, the ELPSO method have the unique benefit for adopts different changes as for current worldwide best positions, for example, Gaussian, Cauchy, turn around and basic transformations. Toward the finish of the transformation procedure, one cycle finishes and a new leader i.e. the =best particle'emerges[8].Different transformations that help this method to accomplish global locations. 


\section{E. Improved SuDoKu Reconfiguration Technique}

It is one of the rearrangement techniques for partial shading conditions that means there is no changes made on the circuit connections of the Photo Voltaic array but just changing the physical area of Photo Voltaic modules. For example the photo voltaic module number 25 is placed at the fifth row-third column of the Total Cross Tied Photo Voltaic array, however, it is bodily adjust to the subsequent line second segment in upgrade $\mathrm{SuDoKu}$ course of action without modifying any changes on the electrical circuit connections. In this manner, all Photo Voltaic modules in the Total Cross Tied Photo Voltaic modules are rearranged as indicated by the upgrade $\mathrm{SuDoKu}$ procedure. This empowers to disseminate the concealed PV modules from a similar column into various lines consistently above the PV exhibit. Therefore, output power of the Photo Voltaic array is increased under the same PSC [9].

\section{F. Intelligent Monkey King Evolution Algorithm}

In this method, A advanced evolutionary based algorithm was introduced for accurate and fast convergence at Maximum Power Point Tracking that is called intelligent monkey king evolutionary (IMKE), which is an advanced version of the MKE algorithm [37]. The MKE algorithm performance mainly depends upon the which Type of parameters are specified by the algorithm it has the good search space, Moreover, in most of the cases, the search of the global and local peaks are extremely near one another, it may be takes longer tracking time and also need large number of iterations to take care of issue circumstances and achieve the GMPP. Therefore, we have a tendency to brisk combining capacity are consolidated with MKE calculation, that has decreased the reliance on formula nominal parameter moreover as rapidly recognizes the GMPP. Besides, due to these enhancements, the Intelligent Monkey King Evolution algorithm speedily converges at MPP, just as the reliance on the underlying point worth and calculation of specified parameters are drastically reduced.

\section{G. Modified $P \& O$ Method}

Due to the some of the downside on the Conventional process First it is lead to transient behavior of around the MPPT condition by the continuous oscillation. Second, the Particle Optimization method is inclined to suffer its following supervision when the irradiance $(\mathrm{G})$ increments quickly [11]. It means that suddenly changing the irradiance due the cloud movement and travelling of some object near the panel. Therefore introduce the Modified P \& O Method in this method objective is to guarantee that steady state oscillation and therefore the deflection from the following locus is decreased. when hunting many perturbation cycles, the operative purpose ought to reach close to the MPP. By then the oscillation round the MPP get in to the result. it's recognize by associate degree perceptive check (which shall be represented later), wherever the desperation size is diminished to a base worth. victimization this procedure, the matter of oscillation is resolved.

\section{H. Shunt Series Compensation Method}

It is one of the methods for MPPT Technique under partial shading conditions some of the drawback is there the connection of By bass diode across each module. A) Power generation of the shaded module is totally lost. B) Tracking of MPPT is complicated due to multiple peaks of power and voltage characteristic [12]. Therefore in this method two compensations are implemented one is current-recompense converter that is associated in parallel with every module, another one is voltage-recompense converter. That is associated in arrangement with every strand. So this compensations are gives the every PV module to work at its exact MPP and convey supreme power.

\section{Enhaced Adaptive $P \& O$ Method}

In this methodology objective is to mitigate the restrictions of the standard Particle Optimization specifically, the steady state oscillation, diverged chase supervision, and incapacity to notice the global peak throughout partial shading. The above mentioned two problems are resolved by using A smart wavering recognition plot and a dynamic limit condition. For the moment, an intelligent prediction method is intended to guarantee that the global peak in every case effectively followed. Another element is the no-load voltage is resolved without utilizing sensors [19].

Table. 1 Comparison of Various MPPT Technique

\begin{tabular}{|c|c|c|}
\hline $\begin{array}{ll}\text { Type } & \text { of } \\
\text { Technique }\end{array}$ & Advantages & Disadvantages \\
\hline $\begin{array}{l}\text { Grey wolf } \\
\text { Optimization } \\
\text { Technique [4] }\end{array}$ & $\begin{array}{l}\text { Tracking speed } \\
\text { is high, There is } \\
\text { no transient } \\
\text { oscillations, } \\
\text { robust, }\end{array}$ & $\begin{array}{l}\text { complexity, } \\
\text { Implementation cost } \\
\text { is high }\end{array}$ \\
\hline $\begin{array}{l}\text { Artificial Bee } \\
\text { Colony } \\
\text { Optimization }\end{array}$ & $\begin{array}{ll}\text { Robust } & \text { and } \\
\text { simple, } & \\
\text { Minimum } & \\
\text { number } & \text { of } \\
\text { control } & \\
\text { parameters } & \text { are } \\
\text { used, } & \end{array}$ & $\begin{array}{l}\text { Tracking speed is } \\
\text { slow, complex, It May } \\
\text { fall on LMPP because } \\
\text { of usage of minimum } \\
\text { number of } \\
\text { control parameters }\end{array}$ \\
\hline $\begin{array}{l}\text { Improved } \\
\text { Curve Tracer }\end{array}$ & $\begin{array}{l}\text { Simple } \\
\text { construction } \\
\text { cost of the } \\
\text { implementation } \\
\text { is very cheap, } \\
\text { there is no } \\
\text { limitation for } \\
\text { tracing under } \\
\text { near Voc }\end{array}$ & $\begin{array}{l}\text { Its May be comes in to } \\
\text { LMPP }\end{array}$ \\
\hline
\end{tabular}




\begin{tabular}{|c|c|c|}
\hline $\begin{array}{l}\text { Simulated } \\
\text { Annealing } \\
\text { Algorithm }\end{array}$ & \begin{tabular}{|l} 
Converge \\
accurately to \\
GMPP, \\
Minimum \\
number \\
control of \\
parameters \\
required
\end{tabular} & $\begin{array}{l}\text { Computational } \\
\text { complexity is occurs, } \\
\text { Oscillate at the } \\
\text { condition of MPPT, } \\
\text { re-initializations are } \\
\text { required due to the } \\
\text { change in solar } \\
\text { irradiance }\end{array}$ \\
\hline $\begin{array}{l}\text { Hybrid SA and } \\
\text { P \& O method }\end{array}$ & $\begin{array}{l}\text { GMPP and } \\
\text { LMPP are } \\
\text { determined by } \\
\text { using SA and } \\
\text { P\&O Method, } \\
\text { Tracking speed } \\
\text { and } \\
\text { Performance is } \\
\text { High, }\end{array}$ & $\begin{array}{l}\text { Restart involve with } \\
\text { change in weather } \\
\text { condition, } \\
\text { touch to progress the } \\
\text { parameters of SA, } \\
\text { suitable approach } \\
\text { detection is difficult }\end{array}$ \\
\hline $\begin{array}{l}\text { Hybrid PSO } \\
\text { and P \& O }\end{array}$ & $\begin{array}{l}\text { Minimum } \\
\text { number of } \\
\text { Search space is } \\
\text { required, GMPP } \\
\text { Tracking speed } \\
\text { is high, Steady } \\
\text { state oscillations } \\
\text { are reduced, }\end{array}$ & $\begin{array}{l}\text { Complex control } \\
\text { structure, } \\
\text { implementation of } \\
\text { experiment is very } \\
\text { cost, } \\
\text { Combination cannot } \\
\text { be promise if GMPP } \\
\text { located outside the } \\
\text { search zone }\end{array}$ \\
\hline $\begin{array}{l}\text { Hybrid DEPSO } \\
\text { method }\end{array}$ & $\begin{array}{l}\text { Valid, system } \\
\text { unconstrained, } \\
\text { exact following } \\
\text { under partial } \\
\text { shading } \\
\text { condition with } \\
\text { high following } \\
\text { rate }\end{array}$ & $\begin{array}{lr}\text { Composite } & \\
\text { calculation, } & \text { More } \\
\text { number } & \text { of } \\
\text { specification } & \text { need } \\
\text { be } \\
\text { selected } \\
\text { optimization } & \end{array}$ \\
\hline
\end{tabular}

Table. 2 Converter and controller Topology for various Techniques

\begin{tabular}{|c|c|c|}
\hline $\begin{array}{l}\text { Name of the } \\
\text { Technique }\end{array}$ & Converter & controller \\
\hline $\begin{array}{l}\text { Modified } \\
\text { Incremental } \\
\text { conductance } \\
\text { algorithm [30] }\end{array}$ & SEPIC Converter & PIC controller \\
\hline $\begin{array}{l}\text { Modified velocity } \\
\text { based PSO } \\
\text { algorithm [6] }\end{array}$ & DC-DC Converter & Not specified \\
\hline $\begin{array}{l}\text { Current } \\
\text { compensation } \\
\text { method [7] }\end{array}$ & $\begin{array}{l}\text { Fly-back } \\
\text { Converter }\end{array}$ & Not specified \\
\hline $\begin{array}{l}\text { Enhanced Leader } \\
\text { Particle Swarm } \\
\text { Optimization [8] }\end{array}$ & Boost Converter & $\begin{array}{l}\text { Arduino } \\
\text { controller }\end{array}$ \\
\hline $\begin{array}{l}\text { Intelligent } \\
\text { Monkey King } \\
\text { Evolution } \\
\text { Algorithm [37] }\end{array}$ & Boost Converter & $\begin{array}{l}\text { Dspace Micro lab } \\
\text { box }\end{array}$ \\
\hline $\begin{array}{l}\text { Modified P\& O } \\
\text { Method [11] }\end{array}$ & Boost converter & Dspace controller \\
\hline Shunt $\quad$ Series & Fly-back & Not specified \\
\hline
\end{tabular}

\begin{tabular}{|l|l|l|}
\hline $\begin{array}{l}\text { Compensation } \\
\text { Method [12] }\end{array}$ & Converter & \\
\hline $\begin{array}{l}\text { Hybrid ELPSO - } \\
\text { P\&O Tracking } \\
\text { Technique [8] }\end{array}$ & Boost Converter & $\begin{array}{l}\text { Arduino } \\
\text { Controller }\end{array}$ \\
\hline $\begin{array}{l}\text { New flower } \\
\text { pollination } \\
\text { Algorithm (FPA) } \\
\text { Technique [22] }\end{array}$ & Boost Converter & $\begin{array}{l}\text { Arduino } \\
\text { Controller }\end{array}$ \\
\hline $\begin{array}{l}\text { A Modified P \& O } \\
\text { Technique [11] }\end{array}$ & Boost Converter & $\begin{array}{l}\text { DSPACE Micro } \\
\text { Lab Box }\end{array}$ \\
\hline $\begin{array}{l}\text { JayaDE Mecro } \\
\text { Technique [34] }\end{array}$ & Boost Converter & $\begin{array}{l}\text { DSPACE Micr } \\
\text { Lab Box }\end{array}$ \\
\hline $\begin{array}{l}\text { Modified Beta } \\
\text { Method [40] }\end{array}$ & Buck-Boost & $\begin{array}{l}\text { DSPACE Micro } \\
\text { Lab Box }\end{array}$ \\
\hline $\begin{array}{l}\text { NHS based MPPT } \\
\text { and PNKLMS } \\
\text { based control } \\
\text { Technique [3] }\end{array}$ & Boost Converter & $\begin{array}{l}\text { DSPACE Micro } \\
\text { Lab Box }\end{array}$ \\
\hline
\end{tabular}

\section{CONCLUSION}

In this paper gives brief portrayals of various Present day MPPT algorithms and Techniques those are being utilized in programming package and experimental platform converter sand controller strategy of the MPPT Techniques are used under PSC conditions. This paper include some of the recent hybrid technology of MPPT. Many advanced Photo Voltaic circuit topologies are used to enhance the following execution of the PV system. In this paper Benefits and bad marks of different MPPT procedures are examined to select a reasonable MPPT under PSC. From the different methodologies discussed in this paper it is very confused to choose the which system is the best one. The decision of MPPT primarily relies on the kind of use, availability of hardware, cost, convergence time, proficiency of the system. It can be concluded that there is different number of research scope to choose a reasonable MPPT which can improve the yield effectiveness of PGS.

\section{REFERENCES}

1. Chao Huang, Student Member, IEEE, Long Wang, Student Member, IEEE, Ryan Shun-Cheung Yeung, Member, IEEE,“ A Prediction Model-Guided Jaya Algorithm for the PV System Maximum Power Point Tracking," IEEE transactions on sustainable energy, vol. 9, no. 1, january 2018.

2. Efstratios I. Batzelis, Member, IEEE, Stavros A. Papathanassiou, Senior Member, IEEE and Bikash C. Pal, Fellow, IEEE "PV system control To provide Active Power reserves under partial shading conditions" IEEE Transactions on power electronics, vol. 33, no. 11, November 2018.

3. G. Nishant Kumar, Member, IEEE, Ikhlaq Hussain, Member, IEEE, Bhim Singh, Fellow, IEEE, "Normal Harmonic Search Algorithm Based MPPT for Solar PV system and Integrated with Grid Using Reduced Sensor Approach and PNKLMS Algorithm ," IEEE Transactions on Industry Applications, Vol. 54, no. 6, November/December 2018.

4. Mohanty S, Subudhi B, Ray P K. "A new MPPT using Grey Wolf optimization technique for Photo voltaic system under partial shading conditions IEEE transactions on sustainable energy, 2016;7:181-81985,

5. B. Chao Huang, Long Wang, Huan Long, Xiong Luo, and Jenq-Haur Wang “ A hybrid maximum power point tracking method for photo voltaic array under patial shading condtions," J. Name Stand. Abbrev., in press. 
6. E Tanuj Sen, Nataraj Pragallapati, Vivek Agarwal, Rajneesh Kumar, "Global maxmum power point tracking of pv array under partial shading conditions using a modified particle velocity based PSO tehnique," IET Renewable Power Generation, 2018, Vol. 12 Iss. 5, pp. 555-564

7. Pooja Sharma, Student Member, IEEE, and Vivek Agarwal, Senior Member, IEEE, Exact maximum power point tracing of grid-connected partially shade pv source using current compensation concept" IEEE transactions on power electronics, vol. 29, no. 9, september 2014.

8. J.Praanth ram, Dhanup. S. Pillai, Memer IEEE, N.Rajasekkar, Member ,IEEE and Scott M.Strachan, "Detection and identification of global maximm power point operatioin in solar PV applications using bybrid ELPSO-P\&O tracking technique" IEEE Journal of Emerging and Selected Topics in Power Electronics, JESTPE-2018-04-0295publication.

9. G.Sai krishna, Tukaram Moger, "Improved SuDuKu configuration technique for total cross tied PV array to enhance maximum power under partial shading conditions" Renewable and Sustainable Energy Reviews 109 (2019) 333-348.

10. K.sangeetha , T.Sudhakar babu, N.Sudhakar, N. Rajasekar,” Modeling , analysis and design of efficient maximum power extractioin method for solar PV system" Sustainable Energy Technologies and Assessments 15 (2016) 60-70

11. Jubaer Ahmed, Student Member, IEEE, and Zainal Salam, Member, IEEE.A modified P\& O maximum power point tracking method with reduced oscillation and improved tracking efficiency" IEEE transactions on sustainable energy, vol. 7, no. 4, october 2016.

12. Pooja Sharma and Vivek Agarwal, Senior Member, IEEE," Maximum power extraction from partially shaded PV array using shunt series compensation" IEEE journal of photo voltaic, vol. 4, no. 4, july 2014.

13. R. Sridhar, S. Jeevananthan, S. S. Dash and Pradeep Vishnuram, "A new maxium power tracking in pv system dring partially shaded conditions based on suffled frog leaf algorithm " Journal of Experimental \& Theoretical Artificial Intelligence, 2016.

14. Chao Huang, Student Member, IEEE, Long Wang, Student Member, IEEE, Ryan Shun-Cheung Yeung, Member, IEEE, Zijun Zhang , Member, IEEE, Henry Shu-Hung Chung, Fellow, IEEE, and Alain Bensoussan, Fellow, IEEE, " A prediction model guded jaya algorithm for the PV system maximum power point tracking" IEEE transactions on sustainable energy, vol. 9, no. 1, january 2018.

15. Mostefa Kermadi, Student Member, IEEE, Zainal Salam, Member, IEEE, Jubaer Ahmed, Member, IEEE, and El Madjid Berkouk,"An effective hybrid maximum powewr point trackers of photo votaic arrays for complex partial shading conditions" IEEE transactions on industrial electronics, 2018.

16. Nataraj Pragallapati, Student Member, IEEE, Tanuj Sen, Student Member, IEEE, and Vivek Agarwal, Fellow, IEEE, Adaptive velocity PSO for global maximum power control of a pv array under non uniform irradiation conditions" IEEE Journal of photovoltaics, vol. 7, no. 2, march 2017

17. Jubaer Ahmed, Member, IEEE, and Zainal Salam, Member, IEEE, “An PV system" IEEE transactions on industrial informatics, vol. 13, no. 5, october 2017.

18. Y Dhimish M, Mehrdadi B, Dales M, Chong B, Zhang L, "Seven indicators variations for multiple PV array configurations under partial shading and faulty PV conditions" Renewable Energy (2017).

19. Jubaer Ahmed, Member, IEEE and Zainal Salam, Member, IEEE, “An enhanced adaptive P\&O MPPT for fast and efficient tacking under varying environmental conditions" IEEE transactions on sustainable energy, vol. 9 , no. 3 , july 2018

20. Kari Lappalainen, Seppo Valkealahti, "Analysis of shading periods caused by moving clouds" Solar Energy 135 (2016) 188-196.

21. Alivarani Mohapatra, Byamakesh Nayak, Priti Das, Kanungo Barada Mohanty, "A review on MPPT techniques of PV system under partial shading condition" Renewable and Sustainable Energy Reviews 80 (2017) 854-867.

22. J. Prasanth Ram, N. Rajasekar, "A new global maximum power poin tracking technique for solar photovoltaic (PV) system under partia

23. Jieming Ma, Member, IEEE, Xinyu Pan, Ka Lok Man, Xingshuo Li, Huiqing Wen, , Member, IEEE, and Tiew On Ting, Member, IEEE, "Detection and assessment of partial shading scenarios on photo voltaic strings" IEEE transactions on industry applications, vol. 54, no. 6 , November/December 2018.

24. Hiren Patel and Vivek Agarwal, Senior Member, IEEE, "MATLAB-Based Modeling to Study the Effects of Partial Shading on occurate method for MPPT to detec the partial shading occurrence in a shading conditions (PSC)" Energy (2016) 1-14.

PV Array Characteristics" IEEE transactions on energy conversion, vol. 23, no. 1, march 2008.

25. R. Hariharan, M. Chakkarapani, G. Saravana Ilango, Member, IEEE, and C. Nagamani, Senior Member, IEEE, "A Method to Detect Photovoltaic Array Faults and Partial Shading in PV Systems" IEEE journal of photovoltaics, vol. 6, no. 5, september 2016.

26. Mohamed A. Mohamed, Ahmed A. Zaki Diab, Hegazy Rezk, "Partial Shading Mitigation of PV Systems via Different Meta-Heuristic Techniques, Renewable Energy . 2018.

27. Jubaer Ahmed, Zainal Salam, "A critical evaluation on maximum power point tracking methods for partial shading in PV systems" Renewable and Sustainable Energy Reviews 47(2015)933-953.

28. Anup Anurag, Satarupa Bal, Suman Sourav \& Mrutyunjaya Nanda, "A review of maximum power-point tracking techniques for photovoltaic systems" International Journal of Sustainable Energy, 35:5, 478-501,2018.

29. Kok Soon Tey, Member, IEEE, Saad Mekhilef, Senior Member, IEEE, Mehdi Seyedmahmoudian, Member, IEEE, Ben Horan, Amanullah Than Oo, and Alex Stojcevski, "Improved Differential Evolution-based MPPT Algorithm using SEPIC for PV Systems under Partial Shading Conditions and Load Variation" IEEE Transactions on Industrial Informatics. 2018

30. Kok Soon Tey, Saad Mekhilef, "Modified incremental conductance MPPT algorithm to mitigate inaccurate responses under fast-changing solar irradiation level" Solar Energy 101 (2014) 333-342.

31. Bidyadhar Subudhi, Senior Member, IEEE, and Raseswari Pradhan, "A Comparative Study on Maximum Power Point Tracking Techniques for Photovoltaic Power Systems" IEEE transactions on sustainable energy, vol. 4, no. 1, January 2013.

32. Xingshuo Li, Huiqing Wen, Member, IEEE, Lin Jiang, Member, IEEE, Weidong Xiao, Senior Member, IEEE, Yang Du, Member, IEEE, and Chenhao Zhao, "An Improved MPPT Method for PV System With Fast-Converging Speed and Zero Oscillation" IEEE transactions on industry applications, vol. 52, no. 6, November/December 2016

33. Suneel Raju Pendem and Suresh Mikkili, "Modeling, simulation, and performance analysis of PV array configurations (Series, Series-Parallel, Bridge-Linked, and Honey-Comb) to harvest maximum power under various Partial Shading Conditions" International journal of green energy.2018.

34. Nishant Kumar, Member, IEEE, Ikhlaq Hussain, Member, IEEE, Bhim Singh, Fellow, IEEE, and Bijaya Ketan Panigrahi, Senior Member, IEEE, "Rapid MPPT for Uniformly and Partial ShadedPV System by Using JayaDE Algorithm in Highly Fluctuating Atmospheric Conditions" IEEE transactions on industrial informatics, vol. 13, no. 5 october 2017

35. Nishant Kumar, Member, IEEE, Ikhlaq Hussain, Member, IEEE, Bhim Singh, Fellow, IEEE, and Bijaya Ketan Panigrahi, Senior Member IEEE, "MPPT in Dynamic Condition of Partially Shaded PV MPPT in Dynamic Condition of Partially Shaded PV" IEEE transactions on sustainable energy, vol. 8, no. 3, july 2017.

36. Nishant Kumar, Ikhlaq Hussain, Bhim Singh, Bijay Ketan Panigrahi, "Peak power detection of PS solar PV panel by using WPSCO" IET Renew. Power Gener., 2017, Vol. 11 Iss. 4, pp. 480-489.

37. Nishant Kumar, Member, IEEE, Ikhlaq Hussain, Member, IEEE, Bhim Singh, Fellow, IEEE, and Bijaya Ketan Panigrahi, Senior Member, IEEE, "Maximum Power Peak Detection of Partially Shaded PV Panel by Using Intelligent Monkey King Evolution Algorithm" IEEE transactions on industry applications, vol. 53, no. 6, november/december 2017.

38. Chakkarapani Manickam, Guru Praanesh Raman, Guru Raghav Raman, Saravana Ilango Ganesan, Senior Member, IEEE, and Nagamani Chilakapati, Senior Member, IEEE, "Fireworks Enriched P\&O Algorithm for GMPPT and Detection of Partial Shading in PV Systems" IEEE transactions on power electronics, vol. 32, no. 6, june 2017

39. Alireza Ramyar, Hossein Iman-Eini, Member, IEEE, and Shahrokh Farhangi, Member, IEEE, Global Maximum Power Point Tracking Method for Photovoltaic Arrays Under Partial Shading Conditions" IEEE transactions on industrial electronics, vol. 64, no. 4, april 2017.

40. Xingshuo Li, Student Member, IEEE, Huiqing Wen, Member, IEEE Yihua Hu, Senior Member, IEEE, Lin Jiang, Member, IEEE, and Weidong Xiao, Senior Member, IEEE," Modified Beta Algorithm for GMPPT and Partial Shading Detection in Photovoltaic Systems" IEEE transactions on power electronics, vol. 33, no. 3, march 2018.

41. M.saadsaoud, H.A.Abbassi, S.Kemiche, M.Ouada, "Study of partial shading effect on photo voltaic array with comprehensive simulator for Global MPPT control" International journal of renewable 


\section{AUTHORS PROFILE}

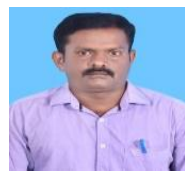

G.Esakkimuthu was born in Eravarpatti, Sivakasi, Tamil Nadu, India. He received his UG degree in Electyrical Engineering from Anna University, Chennai in 2006 and M.E. degree in High Voltage Engineering from Anna university Tirunelveli, Tamil Nadu, India in 2009. Now he is Pursuing $\mathrm{PhD}$ in Kalasalingam Academy of Research and Educations, Krishnankoil, Virudhunagar District, Tamil Nadu and India.

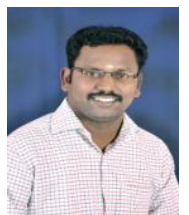

K. Rajesh was born in Rajapalayam, Tamil Nadu, India, in May 1987. He received his UG degree in Electrical Engineering from Anna University, Chennai in 2008 and M.E. degree in Power Systems Engineering from Anna University, Tirunelveli, Tamil Nadu, India, in 2011. Since July 2011, he has been working as an Assistant Professor in the Department of Electrical \& Electronics Engineering, Kalasalingam University, Krishnankoil, Virudhunagar District, Tamil Nadu and India.

He has attended several international conferences and he has been actively involving himself in research since 2013. Three of his research papers have been published in international journals and a research paper has been published in national journal. His current research interests include generation expansion planning, energy planning, power system optimization and power system control. He has actively participated in various faculty development programs, symposiums, orientation programs, workshops and national seminars. He has received Teaching Competency Award in the year 2015 and Research Competency Award in the year 2015 \& 2017. He is a Lifemember of ISTE and Member of IE(I).

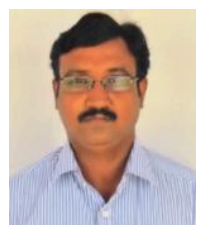

A. Ramkumar received the Ph.D degree from Kalasalingam Academy of Research andEducation in the year of 2014. He received the M.E (Power Systems) degree from Faculty of Engineering and Technology, Annamalai University, Chidambaram, Tamil Nadu, India, in2002 and received the B.E (Electrical and Electronics Engineering) from Thiagarajar Collegeof Engineering, M.K. University, Madurai, Tamil Nadu, India in the year of 1997. He hasbeen working as a Associate Professor in the Department of Electrical and ElectronicsEngineering, Kalasalingam Academy of Research and Education, Srivilliputhur, Tamil Nadu,since 2003. He is having more than 19 years' experience in the field of teaching. His researchinterests include Renewable Energy, Power System Planning, Power System Analysis, HighVoltage DC transmission Systems, Reactive Power Compensation, Flexible ACtransmissions Systems, Electrical Machines and Power System Automation. He is a Lifemember of ISTE and Member of IE(I). 